\title{
The relationship between the ingestion of hot coffee and intraoesophageal temperature
}

\author{
U. W. DE JONG, N. E. DAY, P. L. MOUNIER-KUHN, AND J. P. HAGUENAUER \\ From the Department of Epidemiology and Biostatistics, IARC, Lyon, and the Ear, Nose, and Throat \\ Department, Hôpital Edouard-Herriot, Lyon, France
}

SUMMARY Temperatures at the lower end of the oesophagus were taken during the ingestion of hot coffee at varying temperatures and varying volume, by using a modified duodenal tube.

Temperatures higher than expected were found: of 209 measurements on 17 patients and one volunteer, standardized for size of sip and temperature of coffee, $43 \%$ were $44^{\circ} \mathrm{C}$ or higher (up to $\left.53^{\circ} \mathrm{C}\right)$.

Statistical analysis showed a linear relationship between the intraoesophageal and the initial coffee temperatures.

Volume has a larger effect than the temperature at which the coffee is taken.

The average increase in intraoesophageal temperatures at the point of measurement was $0.381^{\circ} \mathrm{C}$ per $\mathrm{ml}$ coffee ingested.

Some implications of the findings are discussed from the epidemiological point of view.

The temperature at which food and drinks are consumed has been suggested as having a close relationship with cancer of the oesophagus (Watson, 1939; Hirayama, 1955; Burrell, 1957; Tansurat, 1961; Martinez, 1969) but Wynder and Bross (1961) found no such differences between patients and controls. Steiner (1956) stated that 'the temperature of ingested hot food and drinks falls very rapidly so that it is difficult, if not impossible, to achieve injurious temperatures in the lower part of the oesophagus, where most of the tumours occur.'

This communication deals with the questions, What is the temperature of liquids reaching the lower end of the oesophagus in relation to the temperature of ingestion, and what factors influence this temperature?

\section{Materials and Methods}

\section{THERMOMETER}

A two-channel Grant thermometer model B with type $F$ probes was used. These probes are very thin and not suitable for introduction into the oesophagus and were, therefore, placed in a duodenal sonde (Levin type) modified in such a way that the probe could easily be pushed through; its tip was 'guided' to pass the sonde through an orifice at the distal end (Fig. 1).

Received for publication 19 October 1971.

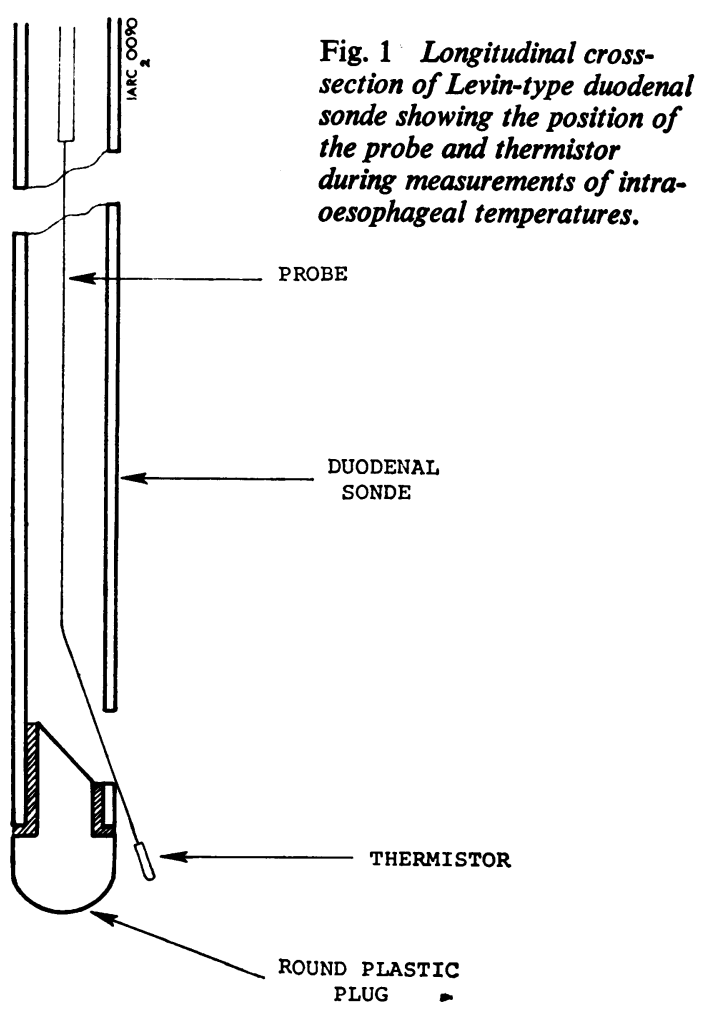


The temperatures were read and recorded by one observer from a needle on a dial. The inertia of the system is quite small because the tips of the probes, containing the thermistor, are very thin $(0.6 \mathrm{~mm}$ in diameter) and will not need much 'warming-up' time. There is a delay of three to five seconds between the immersion of the thermistor in the liquid and the recording of the temperature of that liquid by the needle of the thermometer. The accuracy of the thermometer was $\pm 1^{\circ} \mathrm{C}$.

Measurements at any level inside the oesophagus were possible. The level of the 'internal physiological sphincter' at approximately $38 \mathrm{~cm}$ distance from the incisor teeth was chosen because fluids are delayed here for three to five seconds before entering the stomach. Higher up the oesophagus the passage of liquids may be too rapid for this type of thermometer to record the temperature adequately.

The measurements were done as follows. The sonde with the probe inside was introduced into the oesophagus for $38 \mathrm{~cm}$ and fixed; the probe was then advanced a further $1 \mathrm{~cm}$. The thermistor thus lay outside the sonde $39 \mathrm{~cm}$ from the incisor teeth. The position of the sonde was not checked radioscopically to avoid unnecessary radiation.

Intraoesophageal temperatures were measured at the beginning of each experiment $\left(t_{B}\right)$, immediately before a sip was taken $\left(t_{b}\right)$ and immediately after the sip was swallowed $\left(t_{0}\right) ; t_{0}-t_{b}$ presents the increase in temperature inside the oesophagus at the point of measurement caused by the passage of fluid. In addition, readings were taken at intervals of 30,60 , and 90 seconds $\left(t_{1}, t_{2}, t_{3}\right)$ after $t_{0}$ to determine the delay before the intraoesophageal temperature returned to pre-swallow levels $\left(t_{B}\right)$. The five readings- $t_{b}, t_{0}, t_{1}, t_{2}, t_{3}$-represent one series of observation. By doing this, each $t_{0}$ reading can be considered independently from the others.

\section{LIQUID SWALLOWED}

The liquid given was black coffee with sugar; its temperature $(T)$ was measured immediately before a sip was taken. The range chosen for the coffee temperatures was between 55 and $65^{\circ}$, as an investigation among our office workers showed that very few drank coffee at temperatures outside this range.

Hunt (1947) found the mean temperature of hot drinks consumed by medical students to be approximately $60^{\circ} \mathrm{C} \pm 5^{\circ} \mathrm{C}$. There was no significant difference between men and women.

\section{PATIENTS}

Observations were done on patients in the Ear, Nose, and Throat Department of The Edouard-Herriôt Hospital and one healthy volunteer.

\section{EXPERIMENT I}

During the first experiment, six patients and the one healthy volunteer were asked to drink two cups of coffee ( $80 \mathrm{ml}$ each time) in such a way that it resembled their usual pattern; intraoesophageal temperatures at $39 \mathrm{~cm}$ distance from the teeth were recorded as outlined above.

\section{EXPERIMENT 2}

During the second experiment, sip size and coffee temperature were standardized to see whether a relationship between the coffee temperature and the oesophageal temperature exists. Measurements were done on an additional 17 patients and the same healthy volunteer. No patient had difficulty in swallowing the sonde without anaesthesia of the throat; all stated that the act of swallowing was not hindered by the presence of the sonde. Of the 23 patients, all males between 19 and 73 years, eight had malignant diseases of the pharynx-larynx region, five suffered from oral cancer, and 10 had benign disease of the ear, nose, or throat.

\section{Results}

\section{EXPERIMENT 1}

Figure 2 shows graphically that coffee, taken at a temperature between 50 and $70^{\circ} \mathrm{C}$, reaches the lower end of the oesophagus at temperatures between 40 and $50^{\circ}$. The general pattern of the curves is fairly equal, indicating that the possible effect of a diseased state of the oropharynx and hypopharynx is smaller than might have been expected.

\section{EXPERIMENT 2}

In this experiment amounts of coffee of 5,10,15, and $20 \mathrm{ml}$ were given, each volume at a temperature of 55,60 , and $65^{\circ} \mathrm{C}$. Temperatures inside the oesophagus were read as outlined above.

The results are given in Table I, which gives the value of $t_{0}$ at each temperature and for each volume for each of the patients. Some observations are missing, partly due to fatigue in some patients and partly because of coffee temperature of $65^{\circ} \mathrm{C}$ could not always be tolerated. We see that quite often temperatures of $44^{\circ} \mathrm{C}$ or higher were recorded: 90 times out of 209 , ie, $43 \%$.

Figure 3 shows that the average increase of intraoesophageal temperature with increasing coffee temperature is $2-3^{\circ} \mathrm{C}$ whether sips of $5,10,15$, or 20 $\mathrm{ml}$ were taken.

Figure 4 shows that the average increase of intraoesophageal temperature with increasing size of sip is $5-6^{\circ} \mathrm{C}$ whether the coffee temperature is 55,60 , or $65^{\circ} \mathrm{C}$. 
$\mathrm{T}$

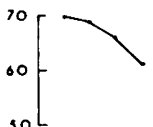

(1)

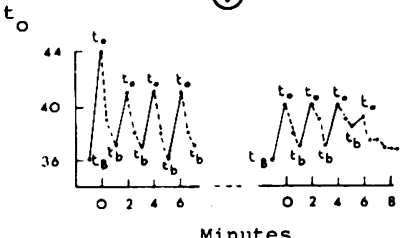

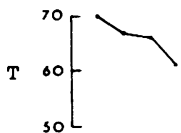

(2)

to

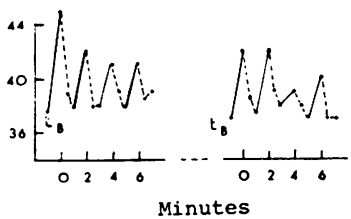

T

${ }_{50}^{80}[$

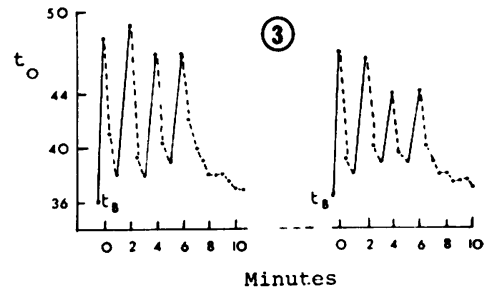

Minutes
(4)

$t_{0}$

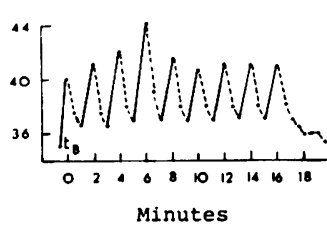

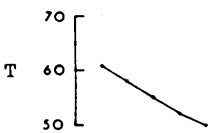

to

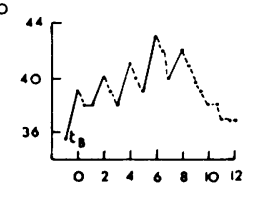

(5)
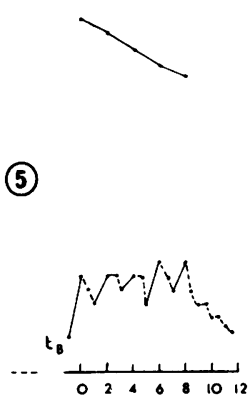

Minutes
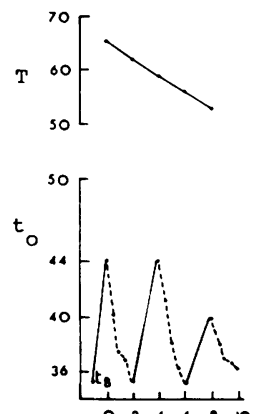

(6)

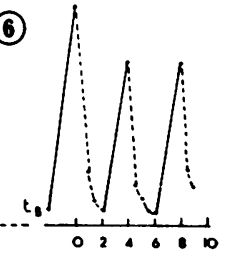

Minutes
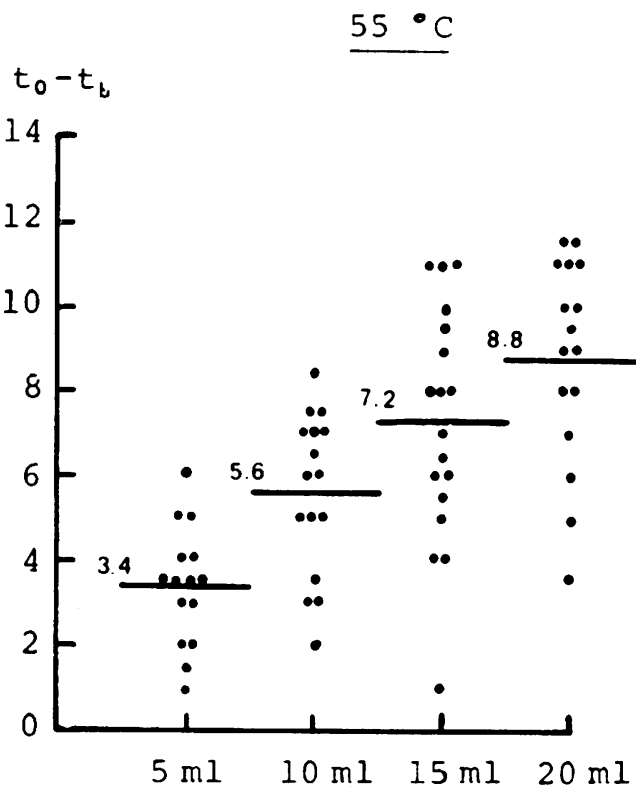

$60^{\circ} \mathrm{C}$

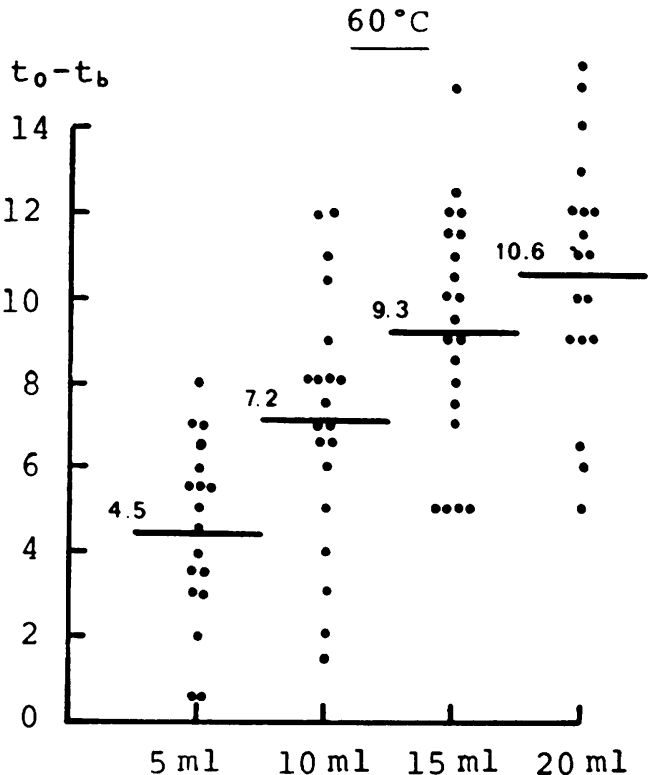

Fig. 2 Intraoesophageal temperatures $\left(t_{0}\right)$ following the drinking of coffee at various temperatures $(\mathrm{T})$, the sip size being determined by the individual.

Each graph is divided into two halves: the upper solid line indicates the coffee temperature $(\mathrm{T})$; the lower line, alternately solid and broken, indicates the intraoesophageal temperature.

$\mathrm{t}_{\mathrm{B}}$ is the intraoesophageal temperature before any coffee was sipped. $\mathrm{t}_{0}$ is the intraoesophageal temperature measured 3-5 seconds after sipping. $\mathrm{t}_{\mathrm{b}}$ represents the intraoesophageal temperature 30 seconds after $\mathrm{t}_{\mathrm{0}}$.

Graph 1 represents a 62-year-old male with oral cancer; graph 2, a 45-year-old male with cancer of the oropharynx: graph 3, a 36-year-old male with a benign vocal cord paresis; graph 4, a 22-year-old male with parotitis; graph 5, a 59-year-old male with cancer of the larynx; graph 6, a 28-year-old healthy male. 


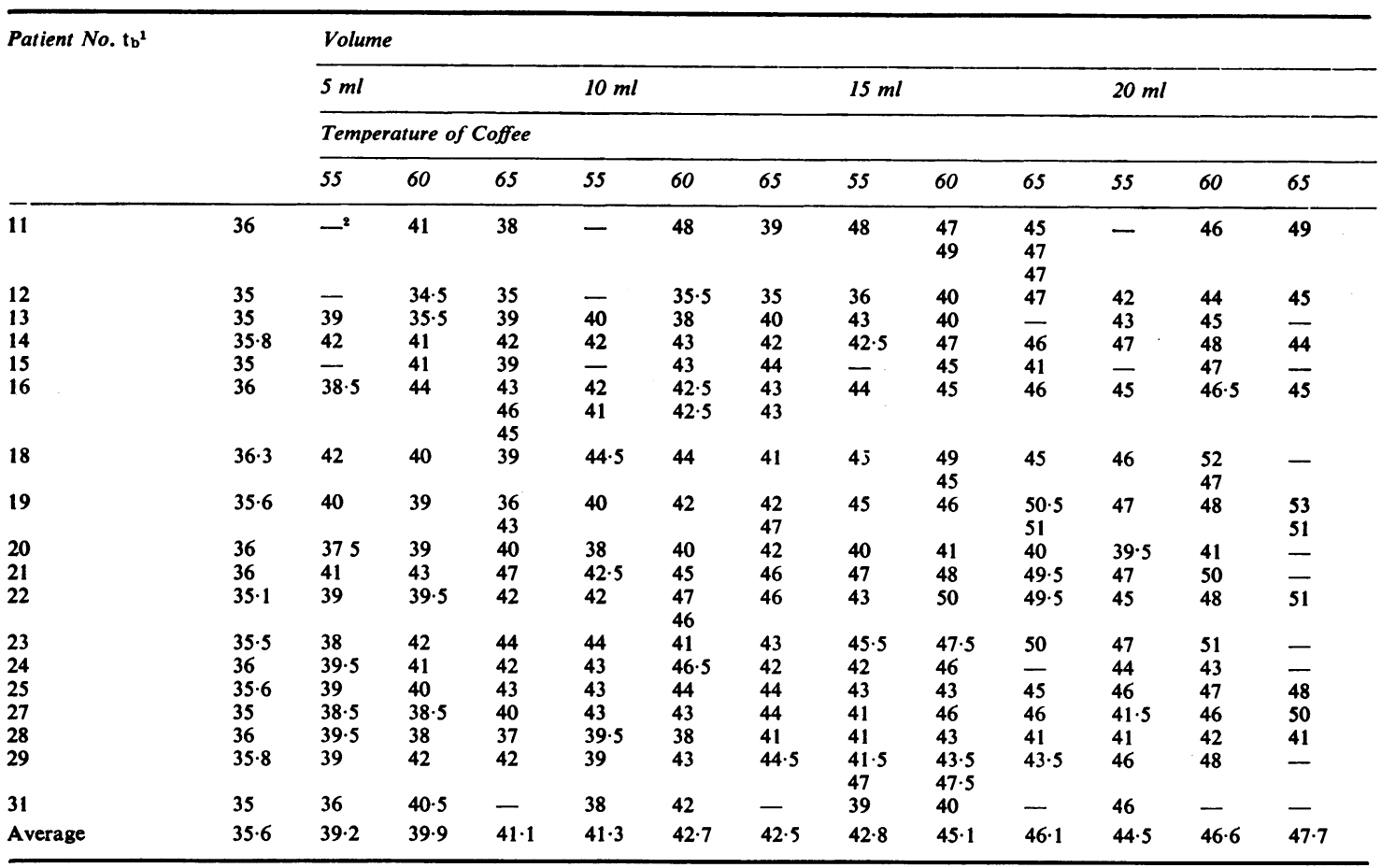

Table I Intrajesophageal temperature $\left(\mathrm{t}_{0}\right)$ by volume given and coffee temperature

${ }^{1}$ No measurement done

${ }^{2} t_{b}$ is the average of intraoesophageal temperatures as recorded immediately before each sip was taken

\begin{tabular}{|c|c|c|c|c|c|c|c|}
\hline $\begin{array}{l}\text { Component of Sum of } \\
\text { Squares }\end{array}$ & $\begin{array}{l}\text { Degrees of } \\
\text { Freedom }\end{array}$ & $\begin{array}{l}\text { Sum of } \\
\text { Squares }\end{array}$ & $\begin{array}{l}\text { Mean Square } \\
\text { Error }\end{array}$ & $\begin{array}{l}\text { Mean Square } \\
\text { Error }\end{array}$ & $\begin{array}{l}\text { Sum of } \\
\text { Squares }\end{array}$ & $\begin{array}{l}\text { Degrees of } \\
\text { Freedom }\end{array}$ & $\begin{array}{l}\text { Component of Sum } \\
\text { of Squares }\end{array}$ \\
\hline $\begin{array}{l}\text { Volume ignoring } \\
\text { temperature } \\
\text { Temperature }\end{array}$ & $\begin{array}{l}3 \\
2\end{array}$ & $\begin{array}{l}896 \cdot 2 \\
238 \cdot 6\end{array}$ & $\begin{array}{l}298 \cdot 4 \\
119 \cdot 3\end{array}$ & $\begin{array}{r}318 \cdot 2 \\
90 \cdot 2\end{array}$ & $\begin{array}{l}954 \cdot 5 \\
180 \cdot 3\end{array}$ & $\begin{array}{l}3 \\
2\end{array}$ & \multirow{3}{*}{$\begin{array}{l}\text { Volume } \\
\text { Temperature } \\
\text { ignoring volume } \\
\text { Interaction } \\
\text { Between cell } \\
\text { Within cell } \\
\text { Total }\end{array}$} \\
\hline $\begin{array}{l}\text { Interaction } \\
\text { Between cell } \\
\text { Within cell }\end{array}$ & $\begin{array}{r}6 \\
11 \\
214\end{array}$ & $\begin{array}{r}26 \cdot 4 \\
1161 \cdot 2 \\
1506 \cdot 5\end{array}$ & $\begin{array}{c}4 \cdot 1 \\
105 \cdot 6 \\
7 \cdot 04\end{array}$ & $\begin{array}{c}4 \cdot 1 \\
105 \cdot 6 \\
7 \cdot 04\end{array}$ & $\begin{array}{r}26 \cdot 4 \\
1161 \cdot 2 \\
1506 \cdot 5\end{array}$ & $\begin{array}{r}6 \\
11 \\
214\end{array}$ & \\
\hline Total & 225 & $2667 \cdot 7$ & & & $2667 \cdot 7$ & 225 & \\
\hline
\end{tabular}

Table II General analysis of variance ${ }^{1}$

'The effects of both volume and temperature are significant at the $0.1 \%$ level. There is no significant interaction between volume and temperature.

These figures indicate that, for the temperaturevolume range used, the effect of the volume is greater than that of temperature.

The significance of these results was assessed by the following analysis of variance.

STATISTICAL ANALYSIS

Due to the unequal number of observations in each volume-temperature cell (see Table I), there is not an orthogonal decomposition of the variance. In the analysis of variance performed, the sum of squares accounted for by one variable has to be evaluated in two ways, first ignoring the second variable, and then taking account of the second variable. The results of this analysis are shown in Table II.

Both the volume and the temperature $(T)$ of the coffee swallowed have a highly significant effect $(P<0.01)$ and, furthermore, the volume has a threefold greater effect than the temperature (T). There appears to be no interaction between the two variables.

The estimated effect on temperature increase, ie, the difference between $t_{0}$ and $t_{b}$ of the different levels of coffee temperature, and its volume are given in 

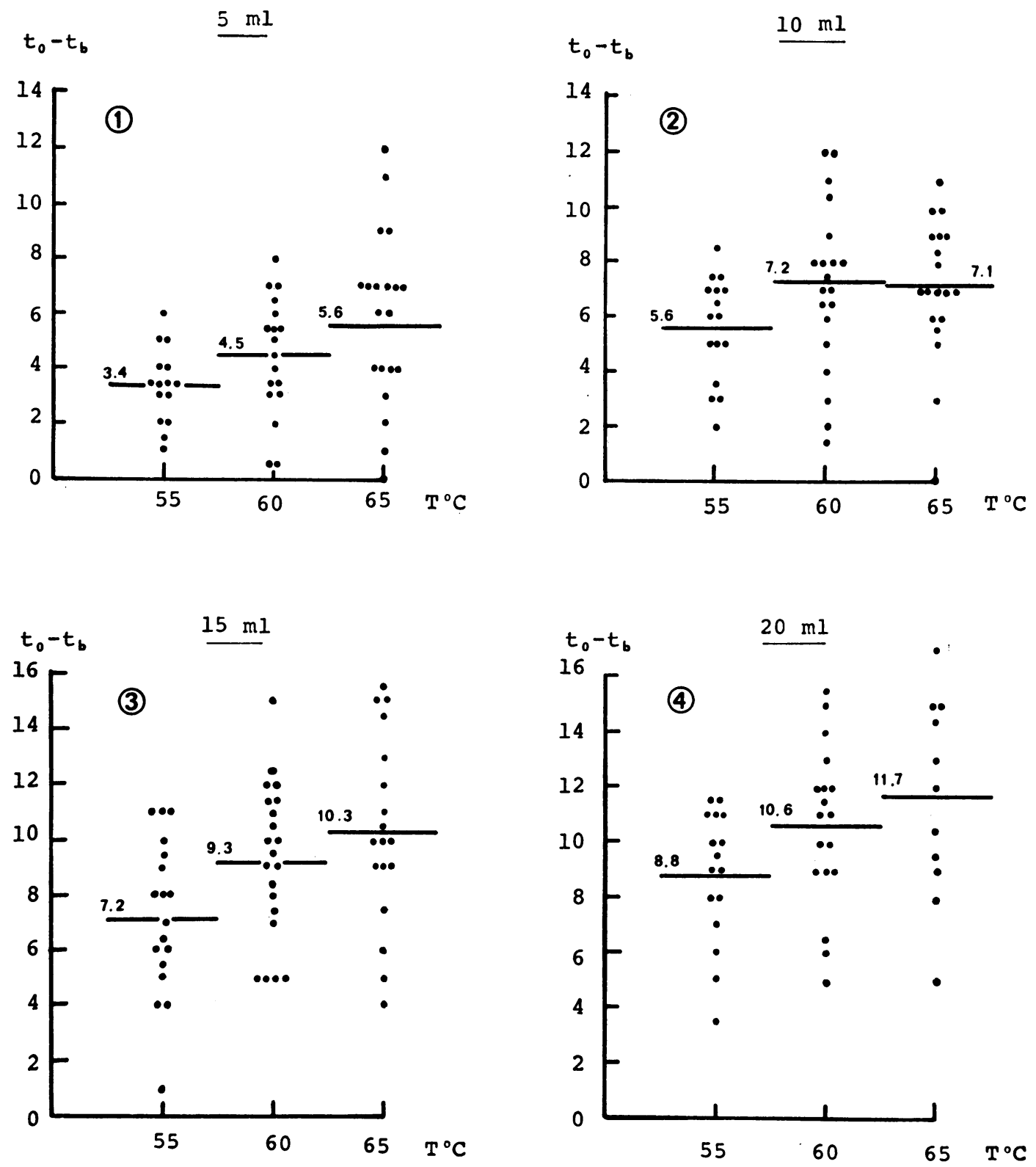

Fig. 3 Increase in intraoesophageal temperature following the drinking of coffee at various temperatures (T) for sips of $5,10,15$, and $20 \mathrm{ml}$.

Each dot represents one swallow and indicates the difference $\left(t_{0}-t_{b}\right)$ in intraoesophageal temperature before and during sipping coffee. Diagrams 1, 2, 3, and 4 represent increases in intraoesophageal temperature when sips of 5, 10,15, and $20 \mathrm{ml}$ respectively were taken at coffee temperatures $(\mathrm{T})$ of 55,60 , and $65^{\circ} \mathrm{C}$; the solid transverse lines in each column indicate the average rise in intraoesophageal temperature per sip size by coffee temperature. 


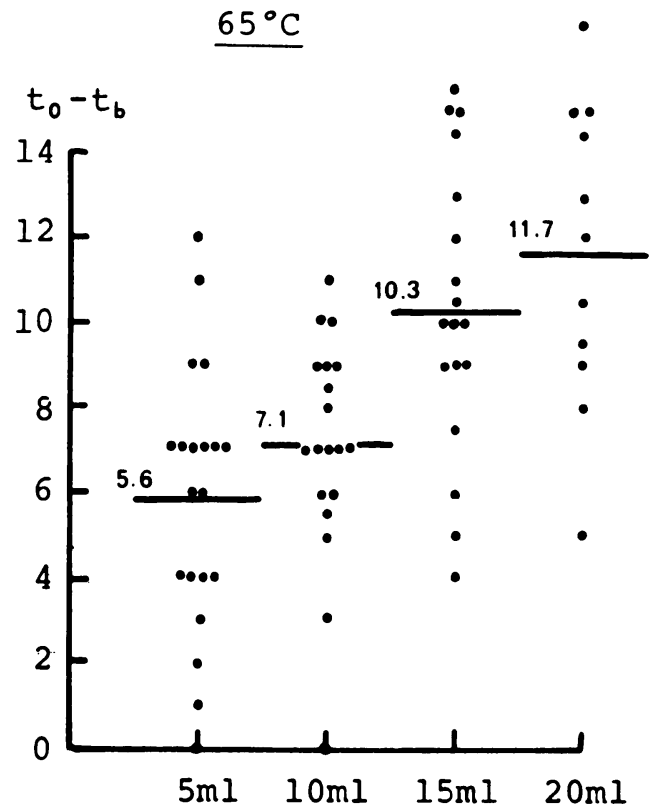

Fig. 4 Increase in intraoesophageal temperature during the drinking of coffee at various sip sizes at a given coffee temperature.

The dots represent the same results as shown in Fig. 2 but are now arranged in a different order, the purpose being to show that sip size has a greater influence on the intraoesophageal temperature than the actual coffee temperature.

Table III. One can see that the effect of volume appears linear, that of temperature nonlinear.

\begin{tabular}{llll}
\hline $\begin{array}{l}\text { Temperature of } \\
\text { Coffee }\left({ }^{\circ} \mathrm{C}\right)\end{array}$ & $\begin{array}{l}\text { Average Increase Volume of } \\
\text { in Temperature Coffee }(\mathrm{ml}) \\
\text { Irrespective of } \\
\text { Sip Size }\left({ }^{\circ} \mathrm{C}\right)\end{array}$ & $\begin{array}{l}\text { Average Increase } \\
\text { in Temperature } \\
\text { Irrespective of } \\
\text { Coffee Tempera- } \\
\text { ture }\left({ }^{\circ} \mathrm{C}\right)\end{array}$ \\
\hline 55 & & 5 & 3.97 \\
60 & 6.19 & 10 & $5 \cdot 70$ \\
65 & 7.89 & 15 & $7 \cdot 89$ \\
& 8.87 & 20 & 9.24 \\
\hline
\end{tabular}

Table III Effect on temperature increase of given coffee temperature and volume

Table IV gives the analysis of variance when each different temperature has a separate parameter fitted but the relationship with volume is linear. The fit as compared with Table II is good. The same linear relationship with volume holds for each of the three initial temperatures.

\begin{tabular}{lrll}
\hline & $D . F$. & S.S. & M.S. \\
\hline Temperature & & & \\
$\quad$ Linear function of volume & 3 & $1,129 \cdot 5$ & $S_{1}^{2}=376.5$ \\
Residual between cells & 8 & $31 \cdot 68$ & $S_{2}^{2}=3.96$ \\
Total between cells & 11 & $1,161 \cdot 2$ & \\
Within cells & 214 & $1,506 \cdot 5$ & \\
Total & 225 & $2,667 \cdot 7$ & \\
\hline
\end{tabular}

Table IV Analysis of variance fitting linear regression for volume

The slope of their relationship is $0.381^{\circ} / \mathrm{ml}$; that is, there is an average increase of $0.381^{\circ}$ in intraoesophageal temperature per $\mathrm{ml}$ coffee swallowed.

\section{Discussion}

The diseased states of the patients may very well modify their way of drinking liquids and the state in which swallowed liquids reach the lower end of the oesophagus. Moreover, whether they are ill or not, personal habits determine the temperature of the liquid when it enters the oesophagus: one person may keep it for a certain length of time in the mouth before swallowing, thus allowing a greater degree of cooling before entering the opening of the oesophagus. Another person may swallow it immediately.

The amount of liquid permitted to leave the oral cavity may differ from person to person and even in the same person: a given amount of $15 \mathrm{ml}$ may be divided up into two or three quick swallows or may be ingested in one. This may explain the wide range of individual variations, as shown in Table I; errors in methodology and the small number of patients involved are also sources of variation. However, in examining Fig. 2 we see that, in general, the patterns of intraoesophageal temperatures in the patients do not differ from each other, with the possible exception of the case with carcinoma of the larynx.

The purpose of this investigation was to see whether, during the ingestion of hot liquids, the temperature at the lower end of the oesophagus increased. We have shown that this does occur and, further, that its relationship with the temperature at which the liquid is swallowed is linear.

This increase of intraoesophageal temperature depends more on the volume swallowed at each sip than on the temperature of the coffee which was swallowed (Table III, Figs. 3 and 4).

If the temperature at which liquids are ingested has a causāl relationship with cancer of the oesophagus (either acting directly on the mucosa inducing 'thermal irritation' or as an aid for the absorption of a carcinogen), then the person who drinks lukewarm $\left(55^{\circ} \mathrm{C}\right)$ coffee or tea rapidly is exposed to a higher risk than he who drinks hot fluids $\left(65^{\circ} \mathrm{C}\right)$ slowly. 

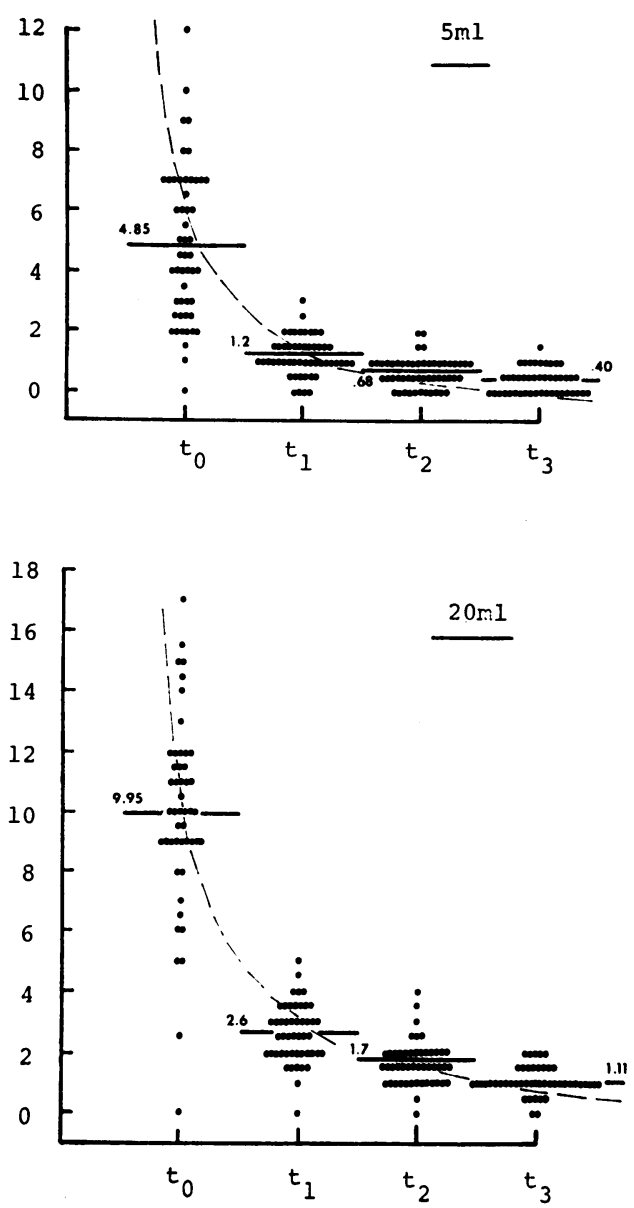

Fig. 5 The decline of intraoesophageal temperature with time. $t_{1}, t_{2}, t_{3}$, represent intraoesophageal temperature measured with 30-second intervals after $t_{0}$, following the ingestion of coffee at temperatures between 55 and $65^{\circ} C^{\text {? }}$. and sip sizes of 5 and $20 \mathrm{ml}$ respectively.

The results of this investigation do not allow any further statement concerning the effect of the intraoesophageal temperatures observed on the mucosa. Moritz and Davis (1966) stated that cellular injury and death occurs if tissue temperature is maintained at a level more than $5^{\circ} \mathrm{C}$ above that which is normal for the blood. The nature and the extent of the injury are determined by the duration of the hyperthermal episode. In our investigation, the duration of the thermal influence is very short, and Fig. 5 shows that within $\mathbf{3 0}$ seconds the intraoesophageal temperature has returned to preswallow level.

As the ranges of temperature and volume used in this experiment correspond with that of normal drinking, this result should be relevant to epidemiological studies. In a study to test the hypothesis that an unusually large increase in oesophageal temperature is a risk factor in cancer of the oesophagus, the more important variable to observe is not the temperature at which liquids are drunk, but the manner of drinking.

The authors are indebted to $\mathrm{Mr} \mathrm{T}$. Greenland for designing the sonde which enabled the introduction of the thermistor into the oesophagus. The authors wish to thank the healthy volunteer for participating in the study.

References

Burrell, R. J. W. (1957). Oesophageal cancer in the Bantu. S. Afr. med. J., 31, 401-409.

Hirayama, T. (1955). Epidemiology of cancer of the oesophagus. $J$. publ. Hlth, 2, 658-663.

Hunt, J. N. (1947). The temperature of choice for hot drinks: a comparison of men and women. Guy's Hosp. Rep., 96, 60-63.

Martinez, I. (1969). Factors associated with cancer of the esophagus, mouth and pharynx in Puerto Rico. J. nat. Cancer Inst., 42, 1069-1094.

Moritz, A. R., and Davis, J. H. (1966). Physical agents in causation of injury and disease. In Pathology, edited by W. A. D. Anderson, 5th ed., vol. 1, pp. 131-133. Mosby, St. Louis; Kimpton, London.

Mounier-Kuhn, P. L., Haguenauer, J. P. and de Jong, U. W. (1970). Etude préliminaire de l'influence des boissons ingérées sur la température de l'oesophage. Societé de Broncho-Oesophagologie et de Gastroscopie de langue française, Paris. Ann. Otolaryng. (Paris). (In press.)

St. Elizabeth Hospital, Curaçao (1970). Working group on oesophageal cancer. (Unpublished material.)

Steiner, P. E. (1956). The etiology and histogenesis of carcinoma of the esophagus. Cancer (Philad.), 9, 436-452.

Tansurat, P. (1961). Cancer of the oral cavity and oesophagus in Thais and Chinese. Acta Un. int. Cancr., 17, 877-880.

Watson, W. L. (1939). Cancer of the esophagus: some etiological considerations. Amer. J. Roentgenol., 41, 420-424.

Wynder, E. L., and Bross, I. J. (1961). A study of etiological factors in cancer of the esophagus. Cancer (Philad.), 14, 389-413. 